\title{
MY BOYHOOD RECOLLECTIONS OF THE SAC AND FOX INDIANS.
}

BY CHAFLES A. WHITE.

Perhaps none of the laws which have been enacted by Congress for the regulation of our dealings with the Indians is now more rigidly enforced than are those which relate to the sale of intoxicating liquors; but for several years after the first settlements were made in Iowa business relations with them were controlled by no such laws. The Indians' thirst for whiskey was irresistible, and no small part of the stock of every trader upon the frontier was devoted to supplying this demand. Indeed, so little was the public conscience then aroused upon this subject that the bottle was a potent and deliberately used influence in overreaching the Indians and its presence, even in treaty assemblies, has been publicly rumored. That rumor accorded with Black Hawk's claim, as a justification of the relentless war which he waged against the whites, that the chiefs of his tribe had been made drunk when they signed the treaty of 1804 ceding to the United States an aggregate of more than twenty-two thousand square miles of land in what are now the states of Missouri, Illinois and Wisconsin; and I am not aware that this accusation was ever disproved. That the Indian signers of that treaty were then drunk seems probable from the fact that they accepted the paltry compensation which was given them, namely, less than twenty-three hundred dollars in hand and an annual payment to the double tribe of one thousand dollars, all in.goods. Black Hawk was a savage, and should be judged as such, but judged righteously; which I believe has not always been done. Even if the contemporary popular reports of his atrocities in war and of his drunkenness after his defeat and humiliation were true, which I neither affirm nor deny, I think there is reason to believe that no more patriotic, no braver or more skillful Indian warrior ever led his people to battle or protected them in defeat. The ear- 
lier recollections of my childhood are connected with popular stories of his savagery, but my subsequent personal contact with his people, the combined Sac* and Fox tribes, was more suggestive of comedy than of tragedy. It was in 1838, the year in which he died and only six years after the close of the war which is still called by his name, that I went with my father's family to live at Burlington, then the principal town on the Upper Mississippi. At that time one portion of the tribe occupied a tract of land bordering the Iowa river, and another portion dwelt on a tract bordering the Des: Moines river, where Black Hawk ended his days. The following remarks are a result of my observations of those Indians, made as a boy of from twelve to sixteen years, and of the life-long impression which they left upon me.

For several years after the date which $I$ have mentioned. parties of the Iowa river division came frequently to trade at Burlington, making the whole journey and return in dugout canoes of their own construction. Their usual campingplace was just above the town and as it was not far from my home I often went there to observe their native customs as well as some of those which had been modified through their contact with the whites. Unfortunately I had little opportunity to observe their virtues and the greater part of what I have to relate pertains to the vice of whiskey.drinking, already referred to. This vice they readily learned from the whites while they were slow to adopt any advantage which civilization offered unless it harmonized with their native customs. For example, because I shall mention their use of iron implements and utensils it is proper to remark that although they discarded rude pottery, flint and bone for industrial uses, they only adapted the more efficient iron to such uses in accordance with their ancient customs, with no wish:

\footnotetext{
*I remember that, in answer to inquiries by white men, I often heard these Indians pronounce their tribal name as if it were written Saw-kee, but I do not know whether that was their own pronunciation or their attempt to give the pronunciation of tho' whito man. In the text of the treaty of 1804 , just roferred to, it was written "Sauke."
} 
or thought of thereby adopting any custom of the white man. But to return to our visitors. In summer time, when the river was low, they sometimes camped upon the gravelly beach, with little shelter; but in cooler weather they pitched their wickeups on the lower end of Flint island just above the northern boundary of the town, or upon the bottom land of the nearer side of Flint slough, which separated the island from the mainland. Except in times of flood this slough, or secondary river channel, was not much more than a canoelength wide, and the lower portion of it was long ago obliterated by that primary instrument of urban improvement, the dump cart.

Their wickeups were sometimes covered with skins and later with strong cotton cloth, but when I first saw their camps the wickeup covering was sometimes of elm or cottonwood bark, which was taken from the trees in spring time, when the sap began to flow. I once witnessed the whole of this process of house building and often saw dead trees still standing that had been thus denuded. The women did this work and when the party reached the camping-place some of them, each with her hand ax, attacked the trees, cutting the bark into proper lengths by making rows of doubly oblique strokes around the trunk. The bark was then removed in sheets by means of the axes and rude wooden wedges. Every sheet when thus removed had notches along each end like huge saw teeth, which were made by the ax cuts. Menntime other women were busy with their axes and knives making the frame of slender willow or cottonwood poles. One of them drove a short stick into the ground for a center, doubled and stretched a string over it, gathered the loose ends in her left hand at the desired length for a radius and then, walking backward with another short stick in her right hand, she marked a perfect circle for the ground plan of her house. The poles were thrust into the soft ground upon this circle and their tips tied together at the top of the structure with strips of bast. The poles were then stayed by tying 
withes horizontally upon them at the proper distances apart to support the sheets of bark to which the latter were tied with strips of bast or slender withes. They were placed with the grain perpendicular upon the frame and lapped to shed the rain, the notched edges giving a rude appearance of neatness to the wickeup. A hole was left at the top for the escape of smoke and another at one side for the entrance, when the conical or dome-shaped house was finished and ready for occupancy. When the party went away the bark was taken down and packed in their canoes for future use.

That case of house building occurred on the lower end of Flint island, but I was obliged to witness it from the mainland shore several rods away, although I was usually allowed to inspect their camping operations at will. The water in the slongh was not deep, but the soft mud at the bottom and shores was, and I could not therefore wade across. The Indians kept their canoes moored to the island side and when they went to town one of the women camp-keepers would push a canoe load of passengers across and pull the empty canoe back by its painter. Members of the party were ferried back to camp in the same manner, but as I had no ticket of invitation I had to content myself with perching upon a big rock which had fallen down from the adjacent bluff. From that point of observation I saw everything clearly and did not get in the way of the workers.

The wickeup of these people was not a dwelling house in our sense of that term. It was a temporary store house for the protection of their goods and a place in which to sleep at night; and also a place wherein to sleep off their drunks, in which debauches the women often joined the men. The cooking and other ordinary work of the camp was done in the open air and I often witnessed those operations. Their food was mostly the game, which they easily procured in that region, supplemented by a little meal or flour obtained by trade. Their cookery was usually a boiling of their food in sheet iron camp kettles. On one occasion I saw the women pre- 
pare what the party evidently regarded as a royal tortoise stew. In summer time, when the falling of the water in the rivers expose the sand bars, the female soft-shelled tortoise comes out to deposit her eggs and cover them with sand, leaving them to be hatched by the sun's rays. Each one deposits a large number of spherical eggs which measure about three-quarters of an inch in diameter. The animal's tracks will usually betray the place where the eggs are deposited; and by lying in wait and running quickly one may catch the tortoise also. On the occasion referred to the tortoise hunters of the party had been very successful, and when I reached their camp a woman had just set out a water bucket nearly full of boiled eggs, which the others began to devour greedily without salt. This mess of eggs was merely an entree, for another woman was busy cutting up several large tortoises for the principal meal. Although the supply was so abundant she was no more wasteful of her material than a Washington chef would be when making terrapin stew. She put into the kettle everything, skin, shell, meat and bones, and even added the entrails after she had passed them botween her fingers to remove their surplus contents. I did not stay to dinner. Perhaps I should not have done so if $I$ had been invited, for I do not even eat the chitterlings that are found in the Washington markets. I was told that their muskrat stews were very good but I never tried them for myself, although $\mathrm{I}$ was then a boy and much given to gastronomical experiments.

In the years of which I write Burlington had a growing population of from 400 to 1,000 white settlers. The principal business was then done in a few low, one-story, unplastered log houses on the river front between Columbia and Arch streets, but after that time Jefferson became the principal business street. The most valuable articles for trade which the Indians brought to town were furs and peltries. The articles they most desired to obtain were calicoes and other cotton cloths, powder and lead and-whiskey. The govern- 
ment furnished them with most of their blankets according to treaty agreement; the cloths, powder and lead were also necessaries, but whiskey was a luxury which few of them were willing to dispense with. The eastern market prices of furs were then low compared with those which afterward prevailed, and the traders made it a rule to give the Indians as little as possible for them. Whiskey also was then very cheap, for the Internal Revenue collector was then unknown. I remember once to have seen it quoted in a St. Louis paper at seventeen cents a gallon by the barrel. The Indians knew all this and would cheat the traders if they got a chance, which was not often. One of their tricks is worth relating as illustrating certain characteristics of both traders and Indians. In one of the trading houses the proprietor had laid some boards, to form a loft under the roof, upon the cross-beams which were only a little above the head of a man of ordinary stature, and as he bought the furs he threw them up there to remain until he had time to pack them. This the Indians also knew, as well as the fact that the whiskey barrel was kept in the back room. One day two Indians came in, one of them having a fine mink skin and an empty pint bottle under his blanket. These he produced and offered the skin for the bottle full of whiskey. The trader readily agreed because a pint of whiskey cost him not more than three cents net. He threw the skin upon the loft and went back to fill the bottle followed by Indian number 1, to see that the whiskey was not watered when it was drawn. Indian number 2 remained in the front room ostensibly to wait for his companion, but really to reach up and pull down that mink skin. When the trader and number 1 returned, number 2 asked to sample the whiskey, which his companion readily allowed. Finding it satisfactory he also produced a fine mink skin and bottle for a similar trade. This was done and the two friends departed, each with a bottle of whiskey at the expense of one mink skin for both.

The taste for whiskey and the comparative ease with which 
those Indians could obtain it had, with few exceptions, a demoralizing effect upon the whole tribe; and the parties who visited Burlington would frequently hold deliberately planned and carefully executed drunks. They would take a quantity of whiskey to camp and appoint at least one woman to remain sober and care for the drunken members, after which she would herself take a solitary spree. The first act of the amazonian guard was to disarm all the others before they began to drink and to see that no weapons were within their reach. Her insignia of office were a stout hickory stick and a bunch of buckskin thongs. The first was to whack the unruly ones and the second to tie their hands and feet if necessary. The men of course opened the carousal and as they began to stretch themselves upon the ground the women, if there were others beside the guard, followed their lords and were soon as drunk as they. It is to their credit that I never saw a child among them on such occasions. They usually had the decency also to hold their orgies in their wickeups, but following is a brief account of one which I witnessed in the summer of 1840 in the open air.

A party of four men and three women had camped without a wickeup just above the present junction of Main and Water streets. It was toward nightfall and the party had returned from their visit to town bringing their whiskey in a tin water bucket. This they had placed upon the ground with several half-pint tin cups around it, and the drunk was in full blast when I reached the place. Indeed, it had passed its culmination, for all the men were lying upon the ground dead drunk. An elderly woman was on guard and of course perfectly sober. The two other women had begun their part in the debauch and were sitting upon a stone, each with her cup of whiskey in hand and each with an arm around the other. They were sipping the liquor and singing a maudlin chant with beaming faces. I went near to get a full view of the show and was angrily ordered away by the guard. I thought it prudent to go, but I only climbed the bank close by, 
which was ten or twelve feet above the party, and that position gave me a better view than I had before. The guard continued to scold and threw stones at me. She could throw better than the average woman, but she did not hit me nor scare me away, although I was the only outsider present. Besides that, her attention was just tinen required by one of the men who had crawled up to the bucket to getanother drink. She did not molest him for this, but when he arose and staggered muttering toward the pile of guns and knives which she had laid aside for safety, she hit him on the head with her stick and he dropped quietly to the ground. The other men were too drunk to get up, but as one of them was trying to do so she had to tie him; and she was otherwise kept too busy to mind me. Meantime the two other women were "gettin'.fou and unco happy." In fact they were already full and there was yet nearly a quart of whiskey before them in the bucket. Moved as by a common impulse each thrust an index finger into her fauces and the immediate result was complete relief of the distended stomach. The suddenness of the relief seemed to daze them for a few minutes but they then returned to their cups and were drinking and singing again when I left them.

During the few years in which those Indians continued their visits to Burlington I witnessed many other incidents illustrative of their wanton habits, the full significance of some of which I did not then clearly perceive. It is my purpose to confine this record of incidents to my boyhood recollections, which are still very distinct, but I may say that in recalling those scenes in after years $I$ fail to recognize that they offered any encouragement for hope of future improvement. Indeed, the article in The Annals for October, 1899 , by Hon. A. D. Bicknell, depicting the present condition of the remnant of the Iowa division of the tribe, which still lives there, shows that they have not only retained all their old antipathy to the civilization of the white man, but that they have really undergone degeneration from their 
primitive condition. These are sad facts for the philanthropist, but let it be understood that the foregoing remarks are made only with reference to the parties which were observed. by myself and to their successors which were discussed by Mr. Bicknell.

The laws which Congress finally enacted prohibiting the sale of intoxicating liquors to the Indians were themselves an open acknowledgment of the former destructive prevalence of the drink evil among them, but it is just to our people to say that the times were then largely at fault, and that the national conscience is now cleaner than formerly in this respect. Repugnant as were such drinking practices as I have just described, they were probably no worse than those which prevailed among our own ancestors and, within the memory of persons now living, among otherwise respectable white men. in connection with some of their social functions. It should: further be said to the credit of the Indians of former years: that although some of their prominent men, especially after their subjugation and humiliation, indulged in drunkenness. others tried hard to induce their people to abandon the use of liquor. I remember, for example, that at the close of a: council which Governor Lucas held in Old Zion church at: Burlington a war-dance was given by a party of Sac and Fox braves as an entertainment to the whites and at the request of the latter. At its close the performers received a liberal contribution and Chief Hard-fish made a speech thanking the donors and vehemently advising the braves not to spend a picayune of it for whiskey. Those former days were pregnant with promise of human improvement, since largely fulfilled as regards the white man, but they were not betterthan these.

Smithsonian Institution, December 5, 1902. 
Copyright of Annals of Iowa is the property of State of Iowa, by \& through the State Historical Society of Iowa and its content may not be copied or emailed to multiple sites or posted to a listserv without the copyright holder's express written permission. However, users may print, download, or email articles for individual use. 